\title{
Disparities in the Implementation of Inclusive Education in Junior High Schools
}

\author{
Muhammad Masrur Huda, Mudjito, Warih Handayaningrum \\ State University of Surabaya, Indonesia \\ masrurpandaan@rocketmail.com
}

\begin{abstract}
The government's policy on inclusive education demands that the implementation of inclusive education of each implementing agency should be in accordance with the standards that have become the reference. However, it is undeniable that every institution has different interpretation about implementing an inclusive education policy. This research aims at describing and analyzing the implementation of inclusion education in Junior High School 36 Surabaya with Junior High School 32 Surabaya in order to reveal the disparity. This research used qualitative descriptive method with multi-site research type. The data were collected through interview with the school principals, coordinators and special escort teachers. Furthermore, direct observation during the learning process was also reinforced through documentation. The results of this study indicated that the implementation of inclusive education among institutions was not similar] seen from the learning management, classroom management, and curriculum management. Those results indicated that there were disparities in the implementation of inclusive education between Junior High School 36 and Junior High School 32.
\end{abstract}

Keywords- inclusive education; Disparity; Special need education

\section{INTRODUCTION}

Education in Indonesia needs improvements for its system that needs to be responsive to changes and demands of the times. The improvement is done from basic education, middle education and higher education which is more equitable and qualified. Therefore, Indonesian people use the education system and the policy pattern in accordance with the Indonesian situation, whether viewed from geographical, sociological and cultural viewpoints. Each condition is developed in the education service process. Recognition of the right to education for every citizen is reinforced in the statement "Every citizen has the same right to obtain quality education" [1]. Moreover, it is also reinforced in various international declarations such as the Universal Declaration of Human Rights (1948), the World Declaration on Education for all (1990), the UN Standard Rules on Equal Opportunities for Persons with Disabilities (1993), Statement of Salamanca and Axis Framework UNESCO (1994).

"Schools should accommodate all children regardless of their physical, intellectual, social, emotional, linguistic or other conditions. This should include disabled and gifted children, street and working children, children from remote or nomadic populations, children from linguistic, ethnic or cultural minorities and children from other disadvantaged or marginalized areas or groups" as stated by Olsen [2]. Inclusion Education is a system of education that provides opportunities for all learners who have abnormalities and have the potential of intelligence or special talents to follow education or learning in the educational environment together with learners in general condition [3]. The inclusion school is a school that houses all students in the same class. The school provides a decent, challenging education program, but matches the abilities and needs of each student, as well as provide help and support in which the teachers can make children believe they can be successful [4]. O'Neil J. defines inclusive education as a system of special education services that requires all children with special needs to be served in the nearest schools in the regular class with friends of their age [5]. Inclusion Education is a system of education that embodies education that values diversity, and is not discriminative for all learners.

The implementation of inclusive education requires the school to make adjustment in terms of the curriculum, educational infrastructure, and learning system tailored to the needs of individual learners. Therefore, accurate identification and assessment processes need to be nurtured by trained and professional personnel in the field in order to be able to develop appropriate and objective education programs.

In inclusion education the curriculum used in the implementation of inclusive education is the applicable curriculum and in accordance with the needs of each of the students with special needs. The teaching and learning process is carried out by taking into account the results of the assessment and the differences in the ability of individual learners with special needs so that they can develop according to their conditions and abilities. The form of the implementation of inclusive education is tailored to the educational unit characteristics of the students with special needs.

In order for inclusive education to work properly, it is necessary to implement inclusive policies, which are therefore 
urgently need implementors who are highly committed, full of willingness, and able to implement the policy.

The organization of special education is done by the government of the United States of America and the United States of America. Educators and education personnel and other stakeholders need to have an awareness that inclusion education is a "vision" rather than an "illusion". The implementation of various policies related to the rights of the government. The children with special needs in Indonesia acquire rights of the implementation of such program. This study focused on inclusive education which also included learning management, classroom management, curriculum management which, in this case, was carried out Junior High School 36 and Junior High School 32 Surabaya.

In the implementation process in inclusive education, the learning is done with the curriculum (adaptation / modification) that has been compiled. The teacher is always active in setting the class adjusting to the learning process. In addition, the teacher gives the learning according to the ability of each child with special needs and brings good communication. In addition, in management, whether this inclusion education runs well or not, it will greatly affect the continuation or development of the inclusive education in the future.

Based on inclusive education research studies done at Junior High School 36, the school has provided various services for children with special needs to get the best and acceptable education, such as in the form of learning management, classroom management in which the students have been given the best service starting from a modified or adaptation curriculum and school curriculum by adapting the ability of special needs students in such classes and timesharing as inclusion, pull-out and special classes. Meanwhile, Junior High School 36 provides experience for direct communication with the surrounding community. They are taught the things dealing with entrepreneurship such as opening salons or haircuts, and many other activities that are considered productive. Various students who are in this Junior High School, among others: deaf students, mild mentally disabled students, moderate mentally disabled students, disabled students, AD / HD, autist, and slow learners.

The implementation of Education Inclusion in Junior High School 32 is not much different from the implementation of inclusive education in Junior High School 36. In addition, to the process and management of the implementation of learning management, classroom management and curriculum management implemented are similar to Junior High School 32. Who becomes a distinct uniqueness in the implementation of inclusive education in Junior 32 is about the field of sports or athletics. It is in accordance with the motto of Junior High School 32 that there is no day without achievement.
Thus, although the same operational policies and standards have been established for the implementation of the same inclusive education, each institution has different implementation. The resources are not always the same to provide services that are acceptable for the aforementioned students. From this case, it emerges disparities or differences in the implementation of inclusive education between institutions of education inclusion. Through this research, the disparities in implementing inclusive education was analyzed to know how the implementation of inclusive education in Junior High School 36 and in Junior High School 32 Surabaya in terms of their learning management, classroom management, and curriculum management.

\section{METHOD}

This research looked for the disparities or differences in the implementation of inclusive education between two Junior High Schools, namely Junior High School 36 and Junior High School 32 Surabaya. Therefore, the research design used was descriptive with multi-type cases. This multi-descriptive descriptive research described the same phenomenon in two different schools systematically. The approach used in this research was a qualitative approach. To make the approach clearer, this research used terminologies with broader meaning that included a number of methods such as ethnography, par observation and other observations [6].

The method used in this research was descriptive method with qualitative approach. This qualitative descriptive research was intended to collect data and later on described the implementation of inclusive education at Junior High School 36 with Junior High School 32 Surabaya. The data collection technique used was interview which was conducted with some informants including the inclusion coordinator, GPK, and the subject teachers. Furthermore, the data was strengthened by the result of observation and documentation.

The process of the data analysis in this study used three analytical techniques proposed by Milles and Huberman [7] namely:

\section{1) Data condensation}

"Data condensation refers to the process of selecting, focusing, simplifying, abstracting, and / or transforming data that appears in the completeness of written field records, interview transcripts, documents and other empirical material."

The researcher conducted the condensation on the data or information obtained at Junior High School 36 Surabaya and Junior High School 32 Surabaya.

\section{2) Data display}


"Data display is a collection of compressed information that always produces images and actions, the display helps us understand what is happening and conduct further analysis".

At this stage, the researchers understood the state of the two schools with the appearance or picture of the situation in the school during the implementation of inclusive education and then carried out a continuous analysis.

\section{3) Verification and conclusion}

"verification and conclusions will be taken by looking at the field notes, coding, storage and methods used." After condensing the data and display data the researcher will draw conclusions / verify the data that has been obtained.

Through that way, the researcher concluded and verified using data obtained from Junior High School 36 Surabaya and Junior High School 32 Surabaya after they had been condensed and displayed.

\section{RESULTS AND DISCUSSION}

\section{A. Organizing classes}

Organizing is a grouping of people, tools, tasks, authorities and responsibilities in such a way as to create an organization that can be mobilized as an established unitary activity [8]. Meanwhile, Johnsen and Miriam Skojen [9] describes three principles: a) Every child is included in the local community and in a class or group, b) The school day is fully regulated with cooperative learning tasks with differences in education and flexibility in choosing with all the heart's content, and c) The teacher works together and gets general education knowledge, special and individual learning techniques and training needs and how to appreciate the diversity and differences among individuals in organizing classes.

Meanwhile, organizing classes in inclusive education was implemented by involving various elements of school such as the principal, inclusion education co-ordinator, GPK, subject teachers, and psychologists. It is in line with Leslie C. Soodak's idea that teachers' ability to identify classroom management policies and practices will demonstrate the diversity of inclusive classes. All students, regardless of their differences, are involved in the learning process [10].

Based on the findings of the research in case 1 and case 2, both cases have differences in the implementation of classroom organization dealing with inclusive schools. The cases dealt with the available class services. In case 1, the school had implemented a new class service that was a pullout which was not in the general guidelines of inclusive education (2011: 27-28). Meanwhile, case 2 had not implemented pull-out class model.

The findings of model in case 1 were pull-out class that dealt with learning with regular learners in the classroom, but in certain time, they were drawn from regular class to source room with special escort teacher. In that case, the classroom organization included: inclusion class, Pull Out class and special class. Whereas, in case 2, the class organization included: full regular class in which the regular class was not full and there was also special classroom source. In case 2, there were disparities or differences in classroom organization compared to case 1 . Here, it dealt with a non-full regular class learning which was followed by shorter or less full classes. Both cases it were in line with Garnida's opinion that explaining about organizing inclusion classes should be tailored to the needs of the crew [11].

Determination of the second class in the case of organizing class involved the Principal, Coordinator, GPK, Psychologist and Subject Teacher. The results of this study were similar to Bupha, Erawan, and Saihong'sopinion which revealed the importance of active collaboration between the school communit and also the experts in preparing and learning the implementation as its behalf in the Inclusion scheme [12]. It also, at the same time, reinforced the characteristics of inclusive education implementation to involve various sources and support from various parties among other principals, Coordinator, teacher, GPK, and Psychologist. It is in line with the results of Scanlon and Baker's research which found about the importance of the cooperation of all parties involved in the implementation of inclusive education so that the learning objectives can be achieved effectively and optimally [13].

\section{B. Implementation of learning and curriculum management}

The implementation of learning is the implementation of teaching and learning interconnections between teachers and learners. The implementation of learning for crews in inclusive schools was tailored to organize the predetermined learning by applying RPP or PPI in the learning process. The implementation of learning also used a modified national curriculum according to the needs of each crew. Meanwhile, the research results from both cases have applied the modification of curriculum in the form of substitution and omission. Those findings are in accordance with the Guidelines for the Implementation of Inclusive Education in which alternative types of inclusive school curriculum including: (1) National Standard Curriculum which is designed for children with special needs who have above average intelligence; (2) Accommodative curriculum under national standards. This curriculum is reserved for children with special needs who have below average intelligence; and (3) Accommodative curriculum above national standards. It is for the crew who has the potential for intelligence and / or 
special talent. They had been applied by both cases studied in this research. Further modification of the curriculum was also done with the curriculum alignment model recommended in the General Guidelines for the Implementation of Inclusive Education in the form of duplication, modification, substitution and omission. Modification model meant to change the things to be customized. Substitution model (replace) meant replacing the contents of the national standard curriculum removes part / whole contents of the national standard curriculum. The implementation of the curriculum modification in each case became the authority of the subject teachers, and GPK by continuing to collaborate with each other and get approval from the coordinator and principals.

Those findings were in line with the findings of research done by Sunardi, Yusuf, Gunarhadi, Priyono, and Yeager in 186 inclusive schools in several cities in Indonesia including: Bandung, Palembang, Solo, Wonogiri, Sukoharjo, Karangannyar, Boyolali and Makassar, more than $56 \%$ of the studied schools have modified the curriculum in applying learning to children with special needs [14].

The implementation of learning in both cases had been running quite well despite having different learning patterns. In the case of a homeroom teacher and a field teacher collaborated with GPK in providing regular classroom learning. Meanwhile, in a special class, GPK was fully involved in the learning. Furthermore, GPK teachers are particularly important in learning in inclusive schools [15]. Therefore, both cases already implemented good learning pattern, though with different formats. The city of Banda Aceh is where the GPK has a role to provide special assistance and guidance to children with special needs, provide ongoing guidance, collaborate with homeroom teachers and field teachers in providing services to children with special needs [16].

In both cases, in addition to homeroom teacher and subject teacher played a full role in learning. Shadow teachers also played a role in learning for students with special needs in need. It is in line with the results of research done by Zakia who conducted research in four elementary schools in Sukoharjo regency. The result of the research showed that GPK's role in school could not be optimal because it had extra duty as homeroom and, furthermore, the unclearness of GPK's career made the GPK performance did not run smoothly and did not fulfill its role as it should have [17].

The implementation of this lesson was in conformity with the General Guidelines for Inclusive Education Infringement where the homeroom had a role to: create a conducive learning climate so that children feel comfortable learning in the classroom / school, carry out learning activities, assessment, and follow-up in accordance with the predetermined learning plan as well as prepare the program and implement guidance for all students. The role of the teachers in the field of learning in inclusive schools included: 1) Creating a conducive learning climate so that children feel comfortable learning in the classroom / school; 2) Implementing learning activities, assessment and follow-up in accordance with the planned lesson plans / PPI, and 3) providing remidial teaching, enrichment / acceleration for learners in need. The GPK of both cases could perform their roles in learning in inclusive schools which included: Developing academic and non-academic assessment instruments with the assistants and subject teachers, conducting mentoring and / or academic learning for learners with special needs together with homeroom teachers and teachers subjects, providing special service assistance for students with special needs who experience obstacles in following the regular classroom lessons in the form of remission or enrichment, and carrying out special learning in the resource room for the learners in need.

Meanwhile, the shadow teacher was not mentioned its role specifically in the General Guidelines of Inclusive Education Infringement. Based on the research findings, indirectly the shadow teacher could also be considered to replace GPK in both cases, due to the limited number of GPK. Nevertheless, the role of shadow teacher was limited when compared to GPK.

Furthermore, both cases in implementing the learning had fulfilled the stages of implementation of learning activities according to the Directorate of Fostering of SLB which included: (1) implementing apperception, (2) presenting lesson materials / materials, (3) implementing methods, learning resources / materials, and training materials which are appropriate to the initial ability and characteristics of the students, and in accordance with the learning objectives; encouraging students to be actively involved, (5) demonstrating the mastery of the subject matter and its relevance in life, (6) fostering interpersonal relationships, among others such as being open, tolerant, and sympathetic to students; displaying excitement and earnestness; as well as managing interpersonal interactions [18].

Both cases in learning also applied learning methods that vary including lectures, questions and answers, discussions, assignments and demonstrations. It is in line with the results of a research conducted by Lage which explains that there is a need for a variety of learning methods in learning for crews in inclusive schools [19]. Both cases also used the media in the teaching and learning process, either in the form of educative props, or visual media created by the homeroom teacher, subject teachers, and GPK, although the media were less varied. It is in line with the research conducted by Gronlund which found the tendency of applying less varied learning media in developing countries [20]. Furthermore, the implementation of the learning approach for children with 
special needs, which was done by the homeroom teacher, subject teacher, and GPK was good enough that is through special guidance which is in line with Koegel, Matos-Freeden, Lang \& Koegel [21], Tabb, Whiting, \& Wheeler [22]; Gargiulo [23] Koomen [24] in which they reveals that it is important to deal with emotional social approach for children with special needs. Such effort was manifested in developing positive relationships between teachers with crew, as well as crew with other learners. The learning in the special classroom / resource room also went well following the rules of learning modification by applying the learning steps appropriately.

\section{Facilities and infrastructure}

As the schools which implement inclusive education, Junior High School 36 and Junior High School 32 Surabaya required supporting facilities and infrastructures in the implementation of inclusive education. One of the achievements of the learning goals was largely determined by school input. Good input would ensure good teaching and learning process. One of the input components in the research was the availability of learning facilities and infrastructures. The results of research on the availability of infrastructure facilities containing some facilities and infrastructure as follows:

1) Resource Room

2) Learning Media: Computers and APE (Educational Learning Tool)

3) Therapy Tools: Speech Therapy, Occupational Therapy and Self Development

4) Cooking Skills Room.

5) Makeup Room

However, from the infrastructure, there were disparities or differences between Junior High School 36 and Junior High School 32 in which Junior High School 36 had all the means. Meanwhile, Junior High School 32 did not have a cosmetology room. It was because Junior High School 32 did not have program / activities for children with special needs in the field of cosmetology.

\section{Parties or institutions that support inclusive education}

Scanlon and Baker found the importance of the collaboration of all parties involved in implementing inclusive education so that the learning objectives can be achieved effectively and optimally. In implementing inclusive education, there should be a support system or supporting parties which are necessary to accelerate the fulfillment of the access and quality of education for all (Educational for All). The support system might include the support in the form of regulation or government policies or support from the related institutions, among others such as through inclusive education work groups (National, Provincial, District / Municipal level), Source Center for public schools that organize inclusive education, professional teachers, headmasters and school supervisors such as the SD / SLB cluster (KKG, KKS and KKPS), MGMP, MKKS, and MKPS). The support from the other institutions such as LPTK, P4TK TKPLB, and Hall / Training Board as well as Community support were also needed.

Therefore, the implementation of inclusive education Junior High School 36 and Junior High School 32 had cooperated or been supported by several institutions or institutions for the implementation of inclusion education an: MGPK, UNAIR Psychological Institute, UNESA, SMK / SMA in Surabaya for Introduction Majors for further education, SMEs students in Surabaya, SLB or special schools in Surabaya in order to improve the quality of services and educators. However, from the institutions, there were disparity in which Junior High School 36 had cooperation with Hajj Hospital Surabaya and local government clinics. Meanwhile, Junior High School 32 did not cooperate with such hospital and local government clinics at all. It was the disparity or difference between the two schools in terms of the implementation of inclusive education.

\section{CONCLUSION}

Based on the research findings and discussion discussed above, furthermore, the researcher concluded some matters concerning disparities of implementation of inclusive education of Junior High School and Junior High School 32 Surabaya covering class organizing and the implementation of learning management and curriculum, facilities and infrastructure and parties / institution that support the implementation of inclusive education. The details are given as follows:

\section{1) Organizing classes}

The disparity was Junior High School 36 had 3 types of classes of inclusion classes including pullout class and special class while Junior High School 32 had 3 types of classes that were full class, regular but not full class, and special classroom source. There was a disparity between the two schools in the classroom organization.

\section{2) Implementation of classroom management and curriculum}

The disparity was that in inclusion class in Junior High School 36, there were two crews taking national exam such as regular students, while Junior High School 32 for full regular class did not follow UNAS. Then, in pull-out class of Junior 
High School 36, the learning model in some lesson material followed the class condition and other materials in the room source. Meanwhile, in Junior High School 32, regular classes were not full or having shorter learning than regular classes in which the special learning was only carried out in the classroom. The material delivered in pull-out class and special Junior High School 36 more on the functional materials. Meanwhile, in Junior High School 32 in the regular class that was not full, the learning materials were equal to the regular class, while the learning materials in special class were only simplified on its $\mathrm{KD}$. In addition to the subject matter, in this case, it was found that the education staff Junior High School 36 has 2 psychologists and 17 GPK SK, while Junior High School 32 has 1 Psychologist and 4 GPK SK.

\section{3) Facilities and infrastructure}

Junior High School 36 has a Make up Room, while Junior High School 32 did not have it. Such disparity happened because in Junior High School 32 there was no activity of student like Junior High School 36 that having the students doing make up.

\section{4) Parties or institutions that support the implementation of inclusive education}

The existing disparity was that Junior High School 36 was in cooperation with Haji Surabaya Hospital and government local clinics, while Junior High School 32 did not cooperate with any medical institution at all.

They are the disparities or differences between the two schools in the implementation of inclusive education. Such disparities can happen because of different human resources and different capabilities. In addition, each agency has a different purpose or even in the same policy standards but in different implementation in terms of running inclusive education.

\section{REFERENCES}

[1] Undang-undang Republik Indonesia nomor 20 tahun 2003 Bab IV Pasal 5 nomor 1

[2] Hildegunn Olsen, Inclusive Education; A Process Of School Improvement. Bangkok. UNESCO,2001.

[3] Permendiknas Nomor 70 Tahun 2009

[4] Stainback, W. \& Stainback, S, Support Networks For Inclusive Scholing: Independent Integrated education. Baltimore: Paul H. Brooks, 1990.

[5] O'Neil, J. Can Inclusion Work? A Conversation With JamesKauffman an Mara Saphon-Sevin. Educational Leadership,1994.

[6] Yatim Riyanto, Metodologi Penelitian Pendidikan Kualitatif dan Kuantitatif, Unesa University Press, Surabaya,2007.

[7] M. B. Miles, A. Huberman, and J. Saldana, Qualitative data analysis, 3rd edition. SAGE Publication, Inc, 2014.
[8] Siagian, SP. Administrasi Pembangunan, Jakarta: Gunung Agung, 1983

[9] B. H. Johnsen \& M. D. Skjørten, Education - Special Needs Education: An Introduction (pp. 316),2001.

[10] Leslie C. Soodak, "Classroom Management in Inclusive setting” Journal Article: Theory Into Practice, Vol 42. No 4. Published online:24 Juni 2010.

https://www.tandfonline.com/doi/abs/10.1207/s15430421tip4204 10 (di unduh 15 Juli 2018). Pp 327-333, 2010.

[11] Garnida, D, Pendidikan Inklusif Bandung: Refika Aditama,2015

[12] Bubpha, S. et al, Model development for inclusive education management:practical guides for incusive schools. Journal of education and practice 3 (8): 223-230,2012.

[13] Scanlon, David \& Baker, Diana. An Accomodations Model for them secondary inclusive Classroom. Learning Disability Quartely 35 (4) 212224

[14] Sunardi, Munawir Yusuf, Gurnahadi, Priyono, John L, Yeager, The Implementation of inclusive Education for student with Special Needs in Indonesia. Excellence in Higher Education Vol 2 No 1:4-5,2011.

[15] Navarro, Baldiris, et al, Develophing Teachers' Competences for designing Inclusive Learning Experences. Education in Elemntary Schools",2016.

[16] Wati, e., Manajemen Pendidikan Inklusi di Sekolah Dasar Negeri 32 Kota Banda Aceh. Jurnal Ilmiah Didaktika 14 (2): 368-378,2014.

[17] Zakia, Deni Laylatul, Guru Pembimbing Khusus: Pilar Pendidikan Inklusi Surakarta: Poceeding Seminar Pendidikan Nasional,2015.

[18] Direktorat Pembinaan SLB, Pedoman Khusus Penyelenggaraan Pendidikan Inklusif: kegiatan Pembelajaran. Depdiknas, Jakarta,2007.

[19] Lage, et al, Inverting the Classroom: A Gateway to Creating an Inclusive Learning Environtment. Journal of Economic Education 30-43,2000.

[20] Grounlound, Effective Use of Assitive Technologies for Inclusive Education in Develoing Counturies: Issues and Challed From two case studies. International journal of Education and Development Using Information and Communication technology (IJEDICT). 6 (4),2010.

[21] Koegel, Intervention for Childern with Autism Spectrum Disorders in Inclusive Schol Setting. Cognitive and Behavioral Practice Journal. Volume 19, No. 3,2011.

[22] Tabb, Putman Country Sucsesful Use of Best Practice Strategies With Childern With Autism,2013.

[23] Gargiulo, R.M, Special Education in Contemprary Society: An Introdaction to Exceptionality. $4^{\text {th }}$ Edition. USA: Sage Publication,2012.

[24] Koomen, Michel Hollingsworth, Inclusive Science Education: Learning from Wizard. Cultural Study of Science Education 11: 293-325,2016. 